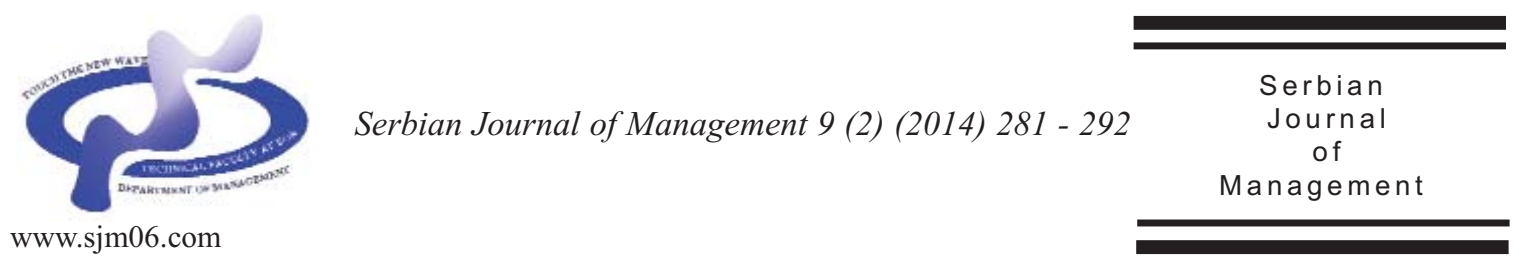

\title{
DIFFERENCES BETWEEN EMPLOYEES AND MANAGERS REGARDING SOCIO-EMOTIONAL COMPETENCES
}

\author{
Gordana Nikića*, Vesna Travica ${ }^{b}$ and Milena Mitrovićc \\ $a_{F a c u l t y}$ of media and communications, Department of social work, \\ Singidunum University, Belgrade, Serbia \\ $b_{\text {Faculty of philosophy, University of Belgrade, Serbia }}$ \\ ${ }^{c}$ Alfa University, Belgrade, Serbia
}

(Received 2 March 2014; accepted 20 August 2014)

\begin{abstract}
The main goal of this paper is to examine differences between employees and managers in attachment styles, emotional intelligence, life satisfaction, personality traits and humour styles, as well to discuss implications of this connection to the quality of management at work. The survey includes 240 participants from Serbia. The sample includes employees and managers of both genders and of a various age.

The instruments used are: Emotional Skills and Competence Questionnaire (Takšić et al., 2006), Experiences in Close Relations (Kamenov \& Jelić, 2003), Personality Questionnaire (Zuckerman, 2002), Humour Styles Questionnaire (Martin et al., 2003) and Satisfaction With Life Scale (Diener et al., 1985).

The results indicate that the owners, top managers and managers in relation to employees have higher scores on all three dimensions of emotional intelligence, dominant affiliative humour style, they are more satisfied with life and show higher activity. Employees have dominant aggressive and self-defeating humour style and neuroticism in relation to owners, managers and top managers.
\end{abstract}

Keywords: attachment style, emotional intelligence, personality traits, humour styles, life satisfaction, management

\section{INTRODUCTION}

The results of numerous studies (Bar-On \& Parker, 2000; Berson \& Yammarino, 2006) show that the main competences related to excellent performance at work are emotional and social qualities: adaptability, self-confidence, persistence, emotion identification and control, empathy, ability to agree with others.

* Corresponding author: gordana.nikic@fmk.edu.rs

DOI:10.5937/sjm9-5440 
The gained results indicate that these competences play more and more significant role on higher levels of management while the differences in professional qualifications are less important. In leading positions almost $90 \%$ competences necessary for success are emotional and social in their nature. In the other words, the higher the position of the leaders who achieve brilliant results, the sooner their efficiency could be attributed to emotional competences.

Employers have seen that the competences of employees connected with emotions are crucial. On the list of desirable characteristics the dominant ones are social and emotional qualities: adaptability in facing to failures and barriers, selfmanagement, self-control, self-confidence, work motivation directed to goals, group and personal efficiency, team work, negotiation skills and potential for leadership (Bar-On \& Parker, 2000).

Employers have a rising need for these qualities of employees nowadays in regard to the modified conditions of business performance and everyday stress which equally affects all the actors, and emotional intelligence at work place is becoming more important than ever before. The global market requires high competition, companies achieve better and larger production with a smaller number of people, and employees should be much more productive in their field of work than it was required from the earlier generations.

One of the most required characteristics at work place nowadays is ability of adaptability, both in changing the work process and with people who are part of the work process. At work place people get in contact and collaborate with the colleagues, who come from different environments, belong to the other cultures and even races. It is, according to Goleman's opinion (Goleman et al., 2006), the reality of today's open market. The fact is that people all over the world experience the same emotions, but different cultures teach people different ways of expressing those emotions. Because of this it is clear why welldeveloped emotional intelligence is important for all actors at work, especially for managers and leaders.

According to Bennis (Bennis, 2002) the basic task of new leaders is to develop good interpersonal relationships and make organisation a pleasant place for human work.

The new trend in organisations is establishing different forms of alliance between leaders and employees. The basic recommendation is that all organisational forms should be taken in consideration except the pyramid with overcome management from the top to the bottom. For new forms of "creative alliance" between leaders, managers and employees, a new set of skills is necessary: ability of perceiving talents, ego negation for the benefit of talents of others, forming and maintaining trust, pointing employees to the sense of what they are doing.

Zohar and Marshall claim that the survival of capitalism implies the change of values, sense and motives, and only in that context we can speak about maintainable organisations and maintainable social system. "We need the feeling of sense and values and the feeling of fundamental purpose to make a fortune that they can generate" (Zohar \& Marshall, 2004).

Psychologists point out that where people involved in team work on common tasks are present there is emotional dynamics within the teams, so perceiving and coping with one's own and others' emotions is the reality 
equally important for all actors.

At the end of last century, psychologists dealt with a new aspect of intelligence which was not included in the former tests emotional intelligence. The authors of the new concept popularly named EQ, Salovey and Mayer, defined emotional intelligence as ability of following and differentiating between one's own and others' emotions and using that information as a guide for thinking and behavior. According to their opinion, the offered definition emphasizes only perception and regulation of emotions, but does not include thinking of emotions. For that reason, they suggest a revised definition according to which emotional intelligence includes ability of quick perception, estimation and expression of emotions, ability of insight and generating emotions which facilitate thinking, ability of understanding emotions and knowledge of emotions, ability of regulation of emotions for purpose of promoting emotional and intellectual development (Salovey \& Mayer, 1990).

Numerous authors have continued their work, among them Bar-On (Bar-On, 2006) who developed one of the first systems for evaluation which uses the term coefficient of emotional intelligence. He defines the purpose of emotional intelligence as an efficient understanding of one's own self and others for forming good interpersonal relationships, and adaptation to the environment for success in satisfying environmental requests. Bar-on claims that EQ develops in the course of time and can be improved using trainings, therapies etc. He claims that individuals with higher EQ are generally more successful in facing environmental requests and pressures. However, it should be taken in consideration that the numerous doubts have been expressed in the referent literature about the validity of this model (Kluemper, 2008).

In recent years researchers have relied more and more on the theory of attachment as one of the dominant psychological theories of the emotional development of personality, theoretically and empirically based on the concept of emotional intelligence.

In psychological researches, the concept of secure attachment style is present more and more, and it is connected with the capacity for leadership and generally for the management process. The concept attachment, first introduced into science by English psychoanalyst Bowlby (Bowlby, 1988) denotes specific, nonsymmetrical relationship formed in the earliest childhood between a mother and a child. The Canadian scientist Mary Ainsworth (Ainsworth et al., 1978) found out through numerous research procedures that the mothers who reacted sensitively and responsively to the signals and needs of their children in the course of the first year of life created the preconditions for secure attachment relationships.

Kim Bartholomew (Bartholomew \& Horowitz, 1991) has defined attachment styles as a four category model, starting with the self-image (dimension anxiety), and image of other (dimension avoidance). According this model, there are one secure and three insecure attachment styles. Secure style has high self-esteem and a positive attitude towards others (low anxiety and avoidance). Secure people have balance between the need for intimacy and the need for autonomy. Preoccupied style has a very strong need for closeness. This style has a negative model of self, low self-esteem and overly positive model of others (high anxiety and low avoidance). Idealization of others is actually defense mechanism of the 
unconscious negative image of others. Dismissing style has overly positive model of self, a very high self-confidence, and a negative model of others (low anxiety and high avoidance). Dismissing is characterized by compulsive self -reliance and selfsufficiency, not investing in relationships, but investing in business and financial matters. Fearful style has a negative model of self and negative model of other (high anxiety and avoidance). Fearful people have low self-esteem and have conflict of motives for closeness and fear of being hurt.

Numerous researches indicate that attachment is important not only for emotional relationships with parents and close relatives, but for all social relations we start through the life span. The researches of social psychologists (Kahn, 1995; Kummel, 1999) show that emotional security is of the crucial importance for most business performance, and also that relationships at work are influenced by the early emotional experiences in family relationships.

So far, the results suggest that the application of this theory on the understanding of the behavior at work is justified, especially when it comes to the relationships with the authority (Kahn, 1995), solutions to the problems of employees (Kummel, 1999), communication strategies (Kummel, 1999), career development (Wright \& Perrone, 2008; Slavic et al., 2014), stress handling and conflict solving (Kahn \& Kram, 1994). Also, it turns out that emotional competences along with intellectual flexibility are of the crucial importance for success of managers (Kummel, 1999) and leaders (Manning, 2003) and also for the estimation and development of capacities for leadership (Berson \& Yammarino, 2006; Popper \& Amit, 2009).
Humour style can be seen as one of the socio-emotional competences. People are fairly consistent in the way they use humour. They can use them to improve themselves or improve relationship with others. Humour can be benevolent or potentially harmful.

According to Martin Rod (Martin, 2007) affiliative humour refers to the tendency to tell jokes, to say funny things and to engage in spontaneous witty banter, in order to amuse others, to facilitate relationships, and to reduce interpersonal tensions.

Self-enhancing humour refers to the tendency to maintain a humorous outlook on life even when one is not with other people, to be frequently amused by the incongruities of life, to maintain a humourous perspective even in the face of stress or adversity, and to use humour in coping.

Aggressive humour is the tendency to use humour for the purpose of criticizing or manipulating others, as in sarcasm, teasing, ridicule, derision, or disparagement humour.

Finally, self-defeating humour involves the use of excessively self-disparaging humour, attempts to amuse others by doing or saying funny things at one's own expense, and laughing along with others when being ridiculed or disparaged. This style of humour is seen as an attempt to gain the attention and approval of others at one's own expense.

A humorous outlook on life and the ability to see the funny side of one's problems may enable individuals to cope more effectively with stress by allowing them to gain perspective and distance themselves from stressful situations, enhancing their feelings of mastery and wellbeing in the face of adversity. As a consequence, these individuals may experience fewer of the adverse effects of stress on their physical health. If this view is correct, therapeutic humour interventions should be viewed as a 
component of stress management training, focusing on teaching individuals ways of using humour to cope with stress in their daily lives.

As Gibson (Gibson, 1994) noted, efforts to promote humour at work are appealing to management as well as employees, since they give both groups a greater feeling of control. At the level of the individual, humour is seen as a tool for gaining control over stress levels and relationships with fellow employees, while it gives organizations a sense of control over their employees, increasing their motivation, productivity, and efficiency. Unfortunately, there does not appear to be any empirical research on the effectiveness of these sorts of humour interventions in business, although their continued popularity suggests that they meet with a receptive audience among both workers and management.

Personality traits could also be seen as characteristics that reflect socio-emotional structure of individual. The alternative five model of personality is based on the claim that the structure of human personality trait is best explained by five broad factors called impulsive sensation seeking, neuroticismanxiety, aggression-hostility, sociability and activity. The model was developed by Marvin Zuckerman and colleagues (Zuckerman, 2002).

The Sensation seeking subscale measures a general need for thrills and excitement, a preference for unpredictable situations and friends, and the need for change and novelty.

Neuroticism-Anxiety subscale describes emotional upset, tension, fearfulness, obsessive indecision, lack of self-confidence, and sensitivity to criticism.

Aggression-Hostility subscale reflects a readiness to express verbal aggression. Other items include rude, thoughtless or antisocial behavior, vengefulness, spitefulness, a quick temper and impatience with others.

Sociability subscale describes a liking of big parties, interacting with many people and having many friends. The second group indicates intolerance for social isolation in highly sociable subjects and a liking or tolerance for isolation in unsociable subjects.

Activity subscale describes the need for general activity and impatience and restlessness when there is nothing to do, a preference for challenging and hard work, and lot of energy for work and other tasks (Zuckerman, 2002).

\section{RESEARCH}

\subsection{Method and goals}

The main objective of this study was to examine if there is a difference between employees and managers in attachment style, emotional intelligence, life satisfaction, personality traits and humour styles.

General hypotheses

The general hypothesis is there a statistically significant difference between employees and managers in following variables: attachment styles, emotional intelligence, life satisfaction, personality traits and humour styles.

\subsection{Sample}

Choosing the sample, we paid attention to have approximately equal number of workers and managers in the companies, to have participants from all parts of Serbia and equal number of male and female participants. The sample is of convenience type and satisfies all the conditions given. The research covered 240 participants. 
According to the sex structure, the sample could be considered equable enough, $45 \%$ of the participants are males, and 55\% females.

About $50 \%$ of the sample are workers, while the other half is constituted by managers and owners, $18 \%$ of which are departments managers, $12,5 \%$ owners, $12,1 \%$ sector managers, $7,5 \%$ top managers. Most of the examinees graduated from the university, and that is $47,5 \%$ of the complete number, $32 \%$ are people who finished only high school, while $15 \%$ of them graduated from college. There are only $5,4 \%$ of those with the highest degree of education. The youngest one is 20 years old, and the oldest 65 , while the average age is 42 . When it comes to the years in the service, the shortest period is a year, the longest 38 and the average age is 17 . The most of the participants have the secure attachment style, almost $84 \%$. Then, there are participants with preoccupied style, $8,3 \%$, while the number of the participants with the dismissing/avoidant style is 4,6\%. Only $2,1 \%$ of the participants have the fearful/avoidant attachment style.

\subsection{Instruments and variables}

Emotional skills and competence questionnaire (ESCQ-45) with 45 items is used for the measuring of emotional intelligence It is a short version of Emotional intelligence questionnaire UEK - 136 (Takšić et al., 2006) constructed according to the model of Salovey and Mayer (Salovey \& Mayer, 1990) and it estimates three aspects of emotional intelligence: capability to perceive and understand emotions (Perceive and Understand Emotions Scale), capability to express and label emotions (Express and Label Emotions Scale), capability to manage emotions (Manage end Regulate emotions scale). All the scales have satisfactory reliability according to different samples, from $\alpha=0,71$ to $\alpha=0,90$.

Personality Questionnaire for estimating dominant personality traits is used for personality type estimation ZKPQ (Zuckerman, 2002). This questionnaire consists of 99 items (a shorter version was used with 50 items, as it was suggested by the author himself) with the binary answer format. The dimensions of this questionnaire are: Activity (Act), Aggression- hostility (Agg-Host), Impulsive searching for sensations (ImpSS), Neuroticism and anxiety (N-Anx) and Sociability (Sy). Correlations on certain sub- scales (Zuckerman, 2002) were: for ImpSS (0.80), for N - Anx (0.84), for Agg - Host (0.78), for Act (0.76) and for Sy $(0.83)$.

Questionnaire for measuring the family attachment is Experiences in Close Relations (Kamenov \& Jelić, 2003). It distinguishes 4 styles of attachment: dismissing avoidant, secure, fearful avoidant and preoccupied. It is a modified instrument (Brenan et al., 1998) which is initially used for measuring attachment in close romantic relationships. It turned out that this new instrument is suitable for measuring family attachment, half shortened, and that the content redundancy is being removed, and almost all the characteristics of the original instrument are being kept. The new economical scale has lost nothing of its reliability.

Humour Styles Questionnaire HSQ (Martin et al., 2003) is used for estimation of the humour styles. HSQ consists of four subscales: Afilitative humour style, Selfenhancing, Aggressive and Self- defeating style. The reliability of the whole scale is expressed with Cronbach's alpha, and it is 0.73 .

Life satisfaction of the participants is 
measured with the Satisfaction with Life Scale-SWLS (Diener et al., 1985). SWLS is cognitive component of subjective wellbeing. The scale consists of five claims which participants answer to with a scale of seven degrees, Likert type.

\section{RESULTS}

The structure and intensity of differences in attachment, life satisfaction, emotional intelligence, humour styles and personality traits depending on socio-demographic characteristics.

We investigated the structure and intensity of the differences in mentioned variables by the set of canonical discriminative analyses in which the criterion variables were the sociodemographic characteristics of participants while the set of predictors were the scores on the subscales of attachment, emotional intelligence and the subscales of humour styles, as well as the overall score on the scale of life satisfaction and the factor scores on the first main components of the subscales of the questionnaire for the estimation of personal traits.

In canonical discriminative analysis the criterion variable is the type of work, and the participants are divided into five groups. The set of predictor variables are the scores on the subscales: humour styles, attachment and emotional intelligence, and also the overall score on the scale of life satisfaction and the factor scores on the first main components of the subscales of questionnaire for estimation of personality traits.

Four discriminative functions are extracted, from which only the first one is statistically significant, on the level of $\mathrm{p}=0,050$ and with the coefficient of canonical correlation $\mathrm{Rc}=0,450$ what means that the existence of difference is evident among the groups of participants, and that difference is of the moderate intensity.

Table 1. Characteristic root, percentage of variance and canonical correlation

\begin{tabular}{ccccc}
\hline Function & $\begin{array}{c}\text { Characteristic } \\
\text { root }\end{array}$ & $\begin{array}{c}\text { Percentage of } \\
\text { variance }\end{array}$ & $\begin{array}{c}\text { Cumulative } \\
\text { percentage }\end{array}$ & $\begin{array}{c}\text { Canonical } \\
\text { correlation }\end{array}$ \\
\hline 1 & .254 & 44.9 & 44.9 & 0.45 \\
2 & .159 & 28.2 & 73.1 & .371 \\
3 & .08 & 14.2 & 87.3 & .273 \\
4 & .072 & 12.7 & 100.0 & 0.26 \\
\hline
\end{tabular}

Table 2. Estimation of importance of discriminative function

\begin{tabular}{ccccc}
\hline Function & $\begin{array}{c}\text { Wilks' } \\
\text { Lambda }\end{array}$ & $\chi^{2}$ & $\begin{array}{c}\text { N of d } \\
\text { freedom }\end{array}$ & $\mathrm{P}$ \\
\hline 1 & .499 & 80.729 & 60 & .050 \\
2 & .745 & 44.493 & 42 & .367 \\
3 & .864 & 22.153 & 26 & .680 \\
4 & .933 & 10.450 & 12 & .577 \\
\hline
\end{tabular}


Table 3. Matrix of the structure of discriminative function

\begin{tabular}{lr}
\hline Aggressive humour style & -.506 \\
Neuroticism- anxiety & -.447 \\
Regulate and manage emotions & .439 \\
Overall life satisfaction & 0.43 \\
Self- defeating humour style & -0.34 \\
Perceive and understand emotions & .322 \\
Sociability & -.165 \\
Affiliative humour style & 0.27 \\
Anxiety & -.058 \\
Express and label emotions & .364 \\
Activity & .384 \\
Avoidance & -.049 \\
Aggression- hostility & -0.09 \\
Self- enhancing humour style & -.019 \\
Impulsive searching for sensations & .004
\end{tabular}

The negative pole of discriminative function is defined by aggressive and selfdefeating humour style and neuroticism as a personal characteristic. The positive pole of discriminative function is defined by all three dimensions of emotional intelligence, affiliative humour style, life satisfaction and activity, as a personal characteristic.

On the basis of values and directions of the centroids of groups we can see that employees are on the negative pole of

Table 4. Centroids of groups

\begin{tabular}{lc}
\hline & 1 \\
\hline Section manager & .113 \\
Sector manager & .249 \\
Top manager /director/ & .371 \\
Owner & .373 \\
Employee & -.230 \\
\hline
\end{tabular}

discriminative function what means that they have dominant aggressive and self-defeating humour style and neuroticism in relation to owners, managers and top managers. Owners and top managers gain almost the same result on the positive pole of discriminative function while the sector managers and section managers gain little lower scores equally on the positive pole of discriminative function. Such result means that owners, top managers and managers in relation to employees have higher scores on all three dimensions of emotional intelligence, dominant affiliative humour style, they are more satisfied with life and show higher activity. Also, top managers and owners have all mentioned characteristics a little more intensive even in relation to managers.

\section{DISCUSSION}

In numerous researches previously done, it turns out that emotional intelligence, besides professional competences, is of the crucial importance on higher levels of management, and emotionally intelligent managers are more efficient at work. The results gained in this research indicate that owners, top managers and managers of middle range in relation to employees have higher scores on all three dimensions of emotional intelligence: ability of perceiving and understanding emotions, ability of expressing and labeling emotions, ability of emotion management. Also, top managers and owners have all the mentioned characteristics a little more intensive than managers of the middle range, which is also in accordance with the previous research.

Numerous findings point to validity of emotional intelligence in the process of the selection and training of the employees (Kerr 
et al., 2006). Certain numbers of the research indicate to the connection between emotional intelligence and efficient leadership (Rosete \& Ciarrochi, 2005). The findings suggest (Palmer et al., 2001) that efficient leaders have the ability to follow and react to behaviour of the employees. One of the conclusions of Mayer and Caruso is that the manager, who can think precisely and clearly about emotions, can be able to predict, bare and efficiently manage the changes (Mayer et al., 2002).

The result of our research that the managers show higher scores in all three dimensions of emotional intelligence implies that the managers in the main processes, like the decision making process, use both cognitive and emotional abilities, which is proved in certain number of researches (Kummel, 1999).

During the past, researchers neglected the question of emotions and emotional processes at work as studies of rage, conflicts, fear of losing the job and uncertain financial future, envy and similar things are.

Numerous researches point out the actuality of studying emotions at work. The studies (Berson \& Yammarino, 2006; Popper \& Amit, 2009) show that emotional stability and intellectual flexibility are the basis for achieving the top results at work, especially in the sphere of management. It is known that employees will accept the tasks from managers much easier if they are in accordance with realistic insight, with very important role of emotional intelligence.

According to the theory of attachment and empirical indicators (Kummel, 1999) emotional security is one of the characteristics that create a precondition for the future management. The managers and leaders of secure attachment are, according to Hazan and Shaver (Hazan \& Shaver,
1990), the only ones with diositions for top results in management.

It is shown in the previous research that the representatives of secure attachment are more satisfied with work and life as a whole, gain better results in choosing mentors, cooperatives, they approach to work more constructively, better find their way in different questions of promotion and career (Wright \& Perrone, 2008; Kahn \& Kram, 1994).

For all the above mentioned, we started with the assumption that employees and managers are different in the terms of attachment styles, but those differences did not prove to be statistically important in this research. The reasons for this could be numerous, from the scale for measuring family attachment to the insufficient number of participants, which would be important to check in some new research by using the other instruments and more representative sample.

This research shows that managers have a dominant affiliative humour style; they are more satisfied with life and show higher activity in relation to employees.

Popular business magazines and books (Duncan \& Feisal, 1989; Kushner, 1990) promote humour at working place. Certain authors claim (Gibson, 1994) that humour at work increases the feeling of self- control and improves the control of the employees by the manager in the terms of motivation and productivity improvement. Humour improves team work, collaboration, employees and manager relationship, better working moral and health, it decreases stress and improves creativity, problem solving and productivity. However, even though we do not have numerous of results, they proved to be controversial (Iaffaldano \& Muchinsky, 1985; Judge et al., 2001). Empirical 
researches of these assumptions are needed.

No matter the fact that we did not get statistically important differences between employees and managers in attachment styles, which we consider to be key defect of this research, we still suppose that emotional security gained in close primary relationships with close persons in childhood and latter close relationships can be precondition for developing permanent social emotional abilities such as emotional intelligence, sociability, the use of humour in stimulating way, why we therefore need new and more thorough research.

\section{CONCLUSION}

On the bases of the gained results we can conclude that owners, top managers and mangers in relation to employees have higher scores on all three dimensions of emotional intelligence, a dominant affiliative humour style, life satisfaction and show higher activity. Also, top managers and owners have all the mentioned characteristics more intensive than managers of the middle range.

It is indisputable that the development of emotional intelligence is crucially important for contemporary leadership, which is also shown in this research. The actualization of studying emotions at work is connected with the business conditions which have changed drastically in recent decades. Traditional organizations gave up their place to modern organizations, and the requests of the turbulent market and the uncertainty in business set new goals for employers. In our uncertain and difficult business environment, all these problems are more dynamised. One of the thinking directions is that we have emotionally intelligent managers and leaders in our environment who work in difficult business conditions. Would eventual changes at the level of system contribute to better expression of their capacities, is one of the questions for the future research.

One of the most important questions is to which extent emotional competences influence results at work. The suggestion for the future research is to focus to results at work of leaders, managers and employees with a sample extension, primarily higher representation of top managers, and also using the other scales for assessing emotional competences. Results about humour styles indicate that this should be an important field of research, especially concerning possible applications of results in stress management.

\section{References}

Ainsworth, M., Blehar, M., Waters, E., \& Wall, S. (1978). Patterns of attachment: A Psychological Study of the Strange Situation. Hillsdale, New Jersey.

Bar-On, R., \& Parker, J.A. (2000). The Handbook of Emotional Intelligence. JosseyBass, San Francisco.

Bar-On, R. (2006). The bar-on model of emotional-social intelligence (ESI). Psicothema, 18, 13-25.

Bartholomew, K., \& Horowitz, M.L. (1991). Attachment styles among young adults: A test of a four-category model. Journal of Personality and Social Psychology, 61, 226-244.

Bennis, W. (2002). Geeks and Geezers: How Era, Values, and Defining Moments Shape Leaders. New York: Harvard Business School Press.

Berson, Y., \& Yammarino, O. (2006). Attachment style and individual differences in 


\title{
РАЗЛИКЕ ИЗМЕБУ МЕНАЏЕРА И ЗАПОСЛЕНИХ У СОЦИО - ЕМОЦИОНАЛНИМ КОМПЕТЕНЦИЈАМА
}

\author{
Гордана Никић, Весна Травица и Милена Митровић
}

\section{Извод}

Главни циљ овог рада је утврђивање разлика између запослених и менаџера у стиловима везивања, емоционалној интелигенцији, стиловима хумора, особинама личности и животном задовољству, као и разматрање импликација ових повезаности на квалитет пословног менаџмента. Истраживање обухвата 240 испитаника из Србије. Узорак чине запослени и менаџери оба пола и различитог узраста.

Коришћени су инструменти: Упитник емоционалне компетентности (Такшић и остали, 2006), Искуства у блиским везама - верзија за процењивање породичне афективне везаности (Каменов и Јелић, 2003), Упитник за процену особина личности (Цукерман, 2002), Упитник стилова хумора (Мартин са сарадницима, 2003) и Упитник Задовољство животом (Диенер, 1985).

Добијени резултати указују да власници, топ менаџери и менаџери имају у односу на запослене више скорове на све три димензије емоционалне интелигенције, да су склонији афилијативном стилу хумора, задовољнији животом и показују већи степен активитета. Запослени имају израженији агресивни и самоподређујући стил хумора и већи степен неуротицизма у односу на топ менаџере, менаџере и власнике.

Кључне речи: стил афективне везаности, емоционална интелигенција, особине личности, стилови хумора, животно задовољство, менаџмент leadership perceptions and emergence.
Journal of Social Psychology, 146 (2), 165182.

Bowlby, J. (1988). A secure base: Parentchild attachment and healthy human development. New York: Basic Books.

Brennan, K.A., Clark, C.L., \& Shaver, P.R. (1998). Self-report measurement of adult attachment. An integrative overview. Pp. 4676 in Simpson J.A., \& Rholes W.S. (Eds.) Attachment theory and close relationships. New York: Guilford Press.

Diener, E., Emmons, R.A., Larsen, R.J., \& Griffin, S. (1985). The Satisfaction with Life Scale. Journal of Personality Assesment, 49, 71-75.

Duncan, W. J., \& Feisal, J. P. (1989). No laughing matter: Patterns of humor in the workplace. Organizational Dynamics, 17 (4), 18-30.

Gibson, D.E. (1994). Humor consulting:
Laughs for power and profit in organizations. Humor: International Journal of Humor Research, 7 (4), 403-428.

Goleman, D., Bojacis, R., \& Maki, E. (2006). Emotional intelligence in leadership. Adidžes, Novi Sad. (In Serbian).

Hazan, C., \& Shaver, P.R. (1990). Love and work: An attachment theoretical perspective. Journal of Personality and Social Psychology, 52, 511-524.

Iaffaldano, M.T., \& Muchinsky, P.M. (1985). Job satisfaction and job performance: A metaanalysis. Psychological Bulletin, 97 (2), 251-273.

Judge, T.A., Thoresen, C.J., Bono, J.E., \& Patton, G.K. (2001). The job satisfaction-job performance relationship: A qualitative and quantitative review. Psychological Bulletin, 127 (3), 376-407.

Kahn, W.A., \& Kram, K.E. (1994). Authority at work: Internal models and their 
organizational consequences. Academy of Management Review, 19 (1), 17-50.

Kahn, W.A. (1995). Organizational change and the provision of a secure base: Lessons from the field. Human Relations, 48 (5), 489514.

Kamenov, Z., \& Jelić, M. (2003). The validation parameter for assessing the degree of attachment in different types of close relationships: Modification of Brennan Inventory of experiences in close relationships. Contemporary Psychology, 6 (1), 73-92.

Kerr, R., Gavin, J., Heaton, N., \& Boyle, E. (2006). Emotional intelligence and leadership effectiveness. Leadership \& Organization Development Journal, 27 (4), 265-279.

Kluemper, D. (2008). Trait emotional intelligence: The impact of core-self evaluations and social desirability. Personality and Individual Differences, 44 (6), 14021412.

Kummel, P.E. (1999). Bringing your family to work: Attachment in the workplace. Doctoral dissertation, Columbia University, New York, USA.

Kushner, M. (1990). The light touch: How to use humor for business success. In. New York: Simon \& Schuster.

Manning, T.T. (2003). Leadership across cultures: attachment style influences. Journal of Leadership \& Organizational Studies, 9 (1), 20-32.

Martin, R.A. (2007). Psychology of Humor: An Integrative Approach. Elsevier Academic Press, Burlington, MA.

Martin, R.A., Puhlik-Doris, P., Larsen, G., Gray, J., \& Weir, K. (2003). Individual differences in uses of humor and their relation to psychological well-being: Development of the Humor Styles Questionnaire. Journal of Research in Personality, 37, 48-75.

Mayer, J.D., Salovey, P., \& Caruso, D.R. (2002). Mayer-Salovey-Caruso Emotional
Intelligence Test (MSCEIT): User's manual. Toronto, Canada: Multi-Health Systems.

Palmer, B., Walls, M., Burgess, Z., \& Stough, C. (2001). Emotional intelligence and effective leadership. Leadership \& Organization Development Journal, 22 (1), 5 10.

Popper, M., \& Amit, K. (2009). Influence of Attachment Styile on Major Psychological Capacites to Lead. The Journal of Genetic Psychology, 170 (3), 244-267.

Rosete, D., \& Ciarrochi, J. (2005). EI and its relationship to workplace performance outcomes of leadership effectiveness. Leadership Organizational Development, 26, 388-399.

Salovey, P., \& Mayer, J.D. (1990). Emotional Intelligence. Imagination, Cognition and Personality, 9, 185-211.

Slavić, A., Berber, N., Leković, B. (2014). Performance management in international human resource management: evidence from the CEE region. Serbian Journal of Management, 9(1), 45-58.

Takšić, V., Mohorić, T., \& Munjas, R. (2006). Emotional inteligence: Theory, operatization, application and connection with positive psychology. Public Research, 4-5, 729-752. (In Serbian)

Wright, S.L., \& Perrone, K.M. (2008). The impact of attachment on carreer related variables: A review of the literature and proposed theoretical framework to guide future research. Journal of Career Development, 35, 87-106.

Zohar, D., \& Marshall, I. (2004). Spiritual capital. Wealth we can live by. San Francisco: Berrett-Koehler.

Zuckerman, M. (2002). ZuckermanKuhlman Personality Questionnaire (ZKPQ): An alternative five factorial model. Pp. 377 396 in DeRaad B., and Peru-sini M. (Eds.), Big Five Assessment, Seattle: Hogrefe and Huber Publishers. 